\title{
The Application of Group Investigation Based on Hands on Activities to Improve Learning Outcomes Based on Higher Order Thinking Skills of Students at SMA Negeri 2 Pematangsiantar
}

\author{
Rosmaulina Adelina Ambarita ${ }^{1}$, Yunastiti $^{2}$, Mintasih Indriayu ${ }^{3}$ \\ ${ }^{1,2,3}$ Sebelas Maret University, Indonesia \\ rosmaulina33@gmail.com
}

\begin{abstract}
The 2013 curriculum currently implemented in Indonesia is one of government attention to the educational world. One of the objectives of the curriculum implementation is the application of learning that is able to improve students' thinking skills which is generally called as higher order thinking skills (HOTS). However, conventional learning that is commonly implemented in Indonesia has not been able to meet the educational objectives. To solve these problems, a relevant learning model is required to improve students learning outcomes based on higher order thinking skills (HOTS). One of the appropriate learning models to solve this issue is the hands on activities investigation group learning model. This model is a learning model with a learning concept in which students are required to play a very active role in building their own knowledge through experiences encountered in groups that will be able to improve student learning outcomes based on higher order thinking skills. This article aimed to explain the ability of group investigation learning model based on hands activities in improving students learning outcomes based on higher order thinking skills. This research was quantitative research with experimental methods. The sample of this study was class X pis student of SMA Negeri 2 Pematangsiantar. The results showed that group investigation learning model based on hands on activities was able to improve learning outcomes based on higher order thinking skills of students at SMA Negeri 2 Pematangsiantar. Keywords : group investigation; hands on activities; learning outcomes; Higher Order Thinking Skills (HOTS)
\end{abstract}

\section{Introduction}

Competition in this globalization era demanding high quality human resources influences several sectors. In the educational world particularly, which is a place to prepare the human to be a good competitor with other individuals. One of the government's efforts to increase the quality of education in Indonesia is by making curriculum changes. Recently, the government implements the 2013 curriculum in which the curriculum is arranged in accordance with this era development that is relevant to the growing needs of the society. Ne of the effects of this curriculum change is on the learning outcomes that must be achieved by students, as written in the Minister of Education and Culture Regulation of 2013 No. 81 regarding curriculum implementation states that the need for future competition is critically required by Higher Order Thinking Skills (HOTS), communication skills and creativity.

Senior High School is one of the formal education in Indonesia. Generally, in this the education level, students learning is dominated by theory delivery, so that to distribute learning material well, it takes a variety of learning models mastered by teachers. In fulfilling these needs, an innovation is required in learning process. In fact, commonly learning process at the high school level is dominated by conventional learning, where this method has not been able to improve student learning outcomes based on higher order thinking skills. In Minister of Education and Culture Regulation No. 64 of 2014 concerning specialization of Secondary Education explains that the 2013 curriculum had a special group division that began to be 
conducted starting from class $\mathrm{X}$. The specialization division was divided into three groups, namely Mathematics and Science, Social, and Language.

Current Economics learning, especially at Senior High School level is a learning using conventional methods. This conventional method makes students to be less actively involved in learning. Also, students will highly depend on teacher and they are less developed to explore more about the material delivered by the teacher. To overcome this problem, we require a learning model that allow students to form their own knowledge, while teacher plays a role in assisting them, so that the knowledge formation process by students can run well. The implementation of this model, will encourage the students to be able to account for their thoughts. Therefore, students will be trained to be understanding, critical, creative, and rational individuals. Of course, this capability will help students in improving their learning outcomes.

SMA Negeri 2 Pematangsiantarl is one of Senior High Schools in Pematangsiantar that has implemented the 2013 curriculum. Based on the observations, it is known that learning process wass dominated by the lecturing method, resulting in a teacher-centered learning process. This will adversely effect on students learning outcomes that is caused by the material delivered is not well understood by students. The monotonous lecture method also affected on students' low interest Economics at school. Therefore, an appropriate change or innovation is required in the process of learning. The expected changes are learning model changes because learning model used will result in the presentation of learning materials to be more interesting for students, easily accepted by students, and classes come alive. (Slameto, 2010: 92). Additionally, students can learn well. Learning model is sought to be appropriate, efficient and effective.

The appropriate learning model applied to overcome these problems is a learning model that adheres to constructivism theory, which is a cooperative learning model that requires students to collaborate in small groups and support each other to increase their own learning and also others. (Jolliffe, 2007) It means that this cooperative learning model is the same as group learning. Cooperative learning is a practical method used to increase motivation and progress in the classroom. According to Chu (2014: 171) group learning also increases selfconfidence, improves communication skills, and increases active participation in the educational process.

Group Investigation learning model is a part of cooperative learning based on observation to overcome the problems in SMA Negeri 2 Pematangsiantar. Group Investigation (GI) is a learning model based on process skills. By implementing this model, it is expected that active interactions between students, in physically, intellectually, and emotionally can be realized. The diversity of students' skills will have a good impact because they can help each other by discussing, collaborating and complementing each other in understanding the subject matter in Economics, particularly market material in the economy. Based on the observations, it was found that the application of the Group Investigation model would be better if it was applied with Hands On Activities based. Since, implementing this model would make students be able to see or touch directly the material they studied in group. Hands on activities is a model designed to involve students in digging up information and asking questions, doing activities, and finding, collecting data and analyzing and then summarizing their own information. Students are free to construct thoughts and findings during the activities, so that students run it without any burdens, but with fun and motivated.

This Group Investigation (GI) based on hands on activities model will support learning to be more interesting and fun, not only for students, but also for teachers. Additionally, market material in the economy on Economics subjects chosen in this study requires a learning model 
that makes students directly involved in understanding the material. In addition, this material requires diverse learning resources that allows students to be free, but it is still in teacher control. In this learning process, students are allowed to be independent in finding out their knowledge to improve their learning outcomes, particularly based on higher order thinking skills. The combination of this model is expected will overcome the problems in Economics learning process in class X of SMA Negeri 2 Pematangsiantar.

This study aimed to investigate the effectiveness of direct practice activities and thoughts on learning achievement and attitudes of class IX students. The results showed that there were significant differences between the average achievement of student learning outcomes in the experimental group. The application of the model is effective in increasing students' achievement.

\subsection{Group Investigation}

\section{Literature Review}

The basics of the cooperative learning model Group Investigation type were designed by Herbet Thelen. The group investigation learning model is the most complex learning model applied (Thelen, 1960) which was later expanded and improved by Sharan and his friends from Tel-Aviv University. This model teaches students to communicate in groups properly (Sharan, 1980). This cooperative learning model group investigation type involves students since planning, both in topic selection and ways to learn the topic through investigation. Marlowe \& Page in Koc, Doymus, Karacop, \& Simsek (2010) argue that group investigation is a cooperative learning model that has characteristics of working in small groups. Students actively build their knowledge to improve their learning outcomes. Cooperative learning model group investigation type on social interaction is one of important factors for mental schemes development because in this learning, students are free to think in an analytical, creative, reflective, and productive manner (Isjoni, 2009). Based on the previous explanation, it can be concluded that group investigation is a learning model that involves students in learning by forming small groups to increase students' active role in conducting teaching and learning activities. Since, in this model students are involved directly to solve various problems encountered, and this model will help students to be more sensitive to see problems and how to overcome the problems. Therefore, there is a possibility for students to increase learning outcomes based on of higher order thinking skills.

\subsection{Hands on Activities}

The hands on activities learning model is also classified as an inquiry learning model. The main characteristic of inquiry learning is that students are guided to find understanding related to the material taught based on the discoveries of the students themselves. Students are also guided to create a creative learning process, encouraged to think and connected to understand with various concepts proposed by the teacher. This is in line with Paul (2017: 123) who states that the hands on activities model contain inquiry, discovery, group work, experiments, etc. After conducting learning activities with this model, students will get an appreciation and experience to establish an understanding (appreciation). This is because students will learn together psychomotor (skills), comprehension (knowledge) and affective (attitudes).

Kartono (2010: 23) points out that hands on activities is a learning model designed to involve students in gaining information and asking questions, doing activities, and finding, collecting data and analyzing and making their own conclusions. Then students are free to 
construct thoughts and findings during the activities so that students conduct it without any burden, but with fun and high motivation. Moreover, Wena (2012: 21) suggests that the Hands On Activities learning model is a learning model in which students do not only see and listen to the teacher explanation, but observe, do and identify directly on the object being studied. This learning model will provide direct experience for students, so that they will be able to overcome learning problems such as difficulty in recalling subject matter.

\subsection{Group Investigation Based on Hands on Activities}

Generally, the concept of group investigation learning model is learning by class planning organization by forming groups of 2-6 student, in which each group is free to choose sub topics from the material taught. Then they are allowed to make or to produce group reports and to present the results of the report to all class which aims to exchange information from students' findings. The hands on activities model has learning planning concept with the existence of artificial objects or concrete objects that are deliberately prepared to further stimulate students' minds in constructing their understanding on the material taught.

From the presentation, the concept raised in the research is a learning concept in which students will play an active role in building their own knowledge through experiences encountered in groups. Therefore, the implementation of learning with group investigation based on hands on activities model is as follows:

a) Identifying topics and organizing students into groups. In this phase, students will choose their own topic from the material prepared by the teacher. Each group consists of students who choose the same topic according to their interests.

b) Facilitating students with prepared props. In this phase, teacher will show pictures and videos as teaching aids for market material in the economy for Economics subject that is going to be discussion material for students.

c) Planning learning tasks. This is planned jointly by students in each group, including: what will be investigated, how to do it, what the responsibility for each member, and what the purpose of the topic investigated is.

d) Conducting investigation. In this phase, students find information, analyze data, and make conclusions from the information conveyed by teachers and worksheets as the complementary sources of market material in the economy. Each group member must contribute to the group effort because later students will exchange, discuss, clarify, and synthesize ideas.

e) Preparing final report. Group members determine the project's essential messages, plan what will be reported and how to make the presentation and form an event committee to coordinate the presentation plan.

f) Presenting the final report. At this phase, the presentation is held for the whole class, the group presentation order will be chosen randomly before the presentation begins. Therefore, each group will not know the order in which they appear and this will make students have readiness at any time to present the results of their group discussions. The parts of presentation must be able to actively engage the listener (other groups), then the listener evaluates the presentation clarity in accordance with the criteria determined by the whole class.

g) Evaluation. Students share the feedback on each topic being worked on, what has been done and their effective experiences. Teachers and students run a collaboration in evaluating learning, while assessment is directed to evaluate concepts understanding as well as creative and critical thinking skills. 


\subsection{Learning Outcomes}

One of indicators that can measure students' success or failure in learning can be seen from student learning outcomes themselves. It shows how the students ability is. Learning outcomes are the results that are used to specifically describe students' ability to understand, knowledge, and attitude at the end of learning (Kettumen, Karisto, \& Penttila, 2013: 337). This is in line with Purwanto (2010: 46) who points out that learning outcomes are changes in student behavior due to the process of teaching and learning activities including cognitive, affective, and psychomotor aspects. Based on this explanation, it can be understood that learning outcomes are a benchmark of learning success, where the results of degrees can also describe students' abilities in cognitive, affective, or psychomotor in mastering subject matter that can be expressed in symbols, letters, or sentences that express results that have been obtained by students from their learning activities.

Students learning outcomes, in this case are influenced by several factors. Generally, it is influenced by external and internal factors. Slameto (2010: 54-59) states that the factors that influence student learning outcomes are classified into two, namely internal factors and external factors. Internal factors are factors coming within the individual, while external factors are factors coming from the individual outside. Further details will be presented as follows:

1. Internal factors include:

a. Physical factors, namely health and disability factors.

b. Psychological factors. There are at least seven factors included in psychological factors that namely: intelligence, attention, interest, talent, maturity and readiness.

c. Fatigue factor, fatigue can be divided into two, namely physical fatigue and spiritual fatigue. Physical fatigue can be identified with the weakness of the body while spiritual fatigue can be identified from the presence of lethargy and boredom so that the interest and motivation to produce something is lost.

2. External factors include:

a. Family factors, students who learn will be influenced by family on the ways parents educate, relationships between family members, household atmosphere, family economic conditions, parents understanding and cultural background.

b. School factors, school factors influence learning including teaching methods, curriculum, teacher relations with students, student relations with other students, school discipline, learning tools, school time, standardized learning on size, building conditions, learning methods and homework.

c. Society factors, society is really influential on student learning. This factor occurs because of students' presence in the society. This factor includes the activities of students in the society, associates, and society lifestyle.

\subsection{Learning Outcomes based HOTS (Higher Order Thinking Skills)}

The future challenges are increasingly demanding the learning done will be able to improve the learning outcomes on higher order thinking skills (HOTS) level. Basically, higher order thinking skills have been studied for a long time by the experts, including research conducted by Bloom in 1956, Resnick in 1987, and Marzano in 1988 and 1992. According to Bloom, higher order thinking skills is an abstract ability that is in the cognitive domain of taxonomy, the education goal which includes analysis, synthesis, and evaluation. Meanwhile, according to Resnick, higher order thinking skills is a mental process involving mental, such as classification, induction, deduction, and reasoning. In addition, according to Adi (2003: 171) higher order thinking skills is a strategy with a high thought process. In this strategy, students 
are encouraged to manipulate information and ideas in certain ways that provide new insights and implications for students.

Generally, high-level thinking skills are determined by the breadth of new challenges utilization. The category of high-level thinking according to Brookhart (2010: 14-15) includes several aspects, as follows:

1. Analysis, evaluation and creation.

2. Logical reasoning

3. Decision and critical thinking

4. Problem solving

5. Creativity and creative thinking

\section{Research Methodology}

This research was a quasi-experimental study. The experimental design used was randomized control group pre-test post-test design. That type of design could be seen on table 1 .

Table 1. Research Design

\begin{tabular}{|c|c|c|c|}
\hline Group (R) & Pre-Test & Treatment & Post-Test \\
\hline $\begin{array}{c}\text { Experiment 1 (Group Investigation Model } \\
\text { based on Hands On Activities) }\end{array}$ & $\mathrm{O}_{1}$ & $\mathrm{X}$ & $\mathrm{O}_{2}$ \\
\hline Control (Group Investigation Model) & $\mathrm{O}_{3}$ & - & $\mathrm{O}_{4}$ \\
\hline
\end{tabular}

\section{Description:}

$\mathrm{R}$ : Experimental and Control Groups of class X students

$\mathrm{O}_{1}$ and $\mathrm{O}_{3}$ : Early learning results using the Pre-test

$\mathrm{O}_{2}$ : The students learning outcomes after attending learning activities with group investigation model based on hands on activities

$\mathrm{O}_{4}$ : Learning outcomes of students group after following the study with group investigation model

$\mathrm{X}$ : Treatment.

This research was conducted at SMA Negeri 2 Pematangsiantar in 2019. The population was all of class X SMA Negeri 2 Pematangsiantar that consist of 9 classes and 338 students. The sample was taken by using simple random sampling. In this study, the sample was class X PIS 2 and X PIS 3 majoring Social Sciences with 38 students in each class.

Techniques of data collection used were observation, documentation, questionnaires and tests. Learning outcomes tests and questionnaires had been validated by lecturers of Economics Education and lecturers of Economics and Business. In this study, testing reliability was conducted by using Cronbach's alpha and obtained values of 0.743 . Since the value is more than 0.5 , it can be said that the instrument is reliable or trusted. Besides analyzing the validity and reliability of the instrument, the analysis was also carried out on the item by computing the level of difficulty of the items and the discrimination power of the questions. After obtaining learning outcomes value, the data were analyzed using paired t-test. 


\section{Discussions}

In this part, we will explain how the results of the research and discussion dealing with the data obtained during the study. Below, the results of the study test will be discussed firs on Table 2 .

Table 2. Learning Test Results

\begin{tabular}{|c|c|c|c|c|}
\hline \multirow{2}{*}{} & \multicolumn{2}{|c|}{ Experiment } & \multicolumn{2}{c|}{ Control } \\
\cline { 2 - 5 } & Pretest & Post-test & Pretest & Post-test \\
\hline Highest Score & 75 & 95 & 75 & 85 \\
\hline Lowest Score & 60 & 80 & 20 & 45 \\
\hline Mean & 67.66 & 84.60 & 54.34 & 67.40 \\
\hline Median & 72 & 74 & 56 & 68.50 \\
\hline Deviation Standard & 7.86 & 6.58 & 14.70 & 12.68 \\
\hline
\end{tabular}

Based on table 2, the highest score for pretest in the experimental class is 75 and the lowest score is 60 . From these results, it can be concluded that the student learning outcomes range is not too wide. Compared to the control class, the highest score is 75 and the score is 20. It clearly has a range that is still quite wide. Moreover, the mean or group average for the experimental class pretest results is higher than the control class, which is equal to 67.66. Whereas the pretest in the control class is 54.34. The learning results on post-test for the experimental class obtained an average of 84.60 with the highest score of 95 and the lowest score of 80 . Therefore, it can be concluded that the range of the score is not too wide compared to the range at the pretest. Compared to the control class, the average score is 67.40 . The highest score is 85 and the lowest score is 45 . This implies that there is a significant difference between the average score of control group and the experimental group.

The next stage is to analyze learning outcomes, so it is required to carry out the t-test firstly. There are two conditions in conducting the test, namely the normality and homogeneity tests. The normality test is conducted to find out whether the sample comes from a distributed population is normal or not. Normality test was done by conducting kolmogorovsmirnov test. In brief, the normality test is presented in the following table 3:

Table 3. Normality Test Results Summary

\begin{tabular}{|l|l|l|l|}
\hline \multicolumn{1}{|c|}{ Variable } & \multicolumn{1}{|c|}{ Statistic Test } & \multicolumn{1}{c|}{ Asymp Sig } & \multicolumn{1}{c|}{ Conclusion } \\
\hline Control Pretest & 0.936 & 0.235 & Normal \\
\hline Control Post-test & 0.959 & 0.568 & Normal \\
\hline Experiment Pretest & 0.912 & 0.092 & Normal \\
\hline Experiment Post-test & 0.914 & 0.099 & Normal \\
\hline
\end{tabular}

Table 3 shows that Asymp. Sig is higher than 0.05, so it can be concluded that the four data are normally distributed. The homogeneity test was carried out to test whether the data group has the same variance or not. The homogeneity test utilized Levene test. The results of the homogeneity test are simply presented on table 4.

Table 4. Homogeneity Test Results Summary

\begin{tabular}{|c|c|c|c|}
\hline Data & Levene Statistic & Significance & Description \\
\hline Pretest & 2.575 & 0.115 & Homogeneous \\
\hline Post-test & 2.470 & 0.126 & Homogeneous \\
\hline
\end{tabular}


Table 4 shows that the significance level for the pretest is 0.115 , this score is more than the significance level of $5 \%$ or 0.05 . It can be concluded that the data is homogeneous. Furthermore, for the post-test of 0.126 that is also higher than the significance level of 0.05 , so it can be concluded that the data is homogeneous as well. After conducting prerequisites test and it is known that the sample is normally distributed and has a homogeneous variance, then a paired t-test can be done. There are two hypothesis tests in this study.

The first hypothesis is to prove whether there are any differences on students learning outcome based on higher order thinking skills and the implementation of group investigation based on hands on activities. This can be proven from the results of the pretest and post-test that have been done.

Table 5. Paired t-test of Learning Test Results Summary

\begin{tabular}{|c|c|c|}
\hline Data & Experimental Group & Control Group \\
\hline Pretest Mean & 67.66 & 54.34 \\
\hline Post-test Mean & 84.60 & 67.40 \\
\hline t count & -7.274 & -4.300 \\
\hline
\end{tabular}

Based on table 5. It is shown that the value of $t$ count in the experimental class is -7.274, so that it can be concluded $\mathrm{P}<0.05$, then Ho is rejected and $\mathrm{Ha}$ is accepted. In conclusion, there are significant differences between the average pretest and post-test. The differences can be seen from the post-test average of 84.60 that is higher than the pretest of 67.66. While for the control class, it can be seen the value of $t$ count of -4.300 , it means that $\mathrm{P}<0.05$, then Ho is rejected and $\mathrm{Ha}$ is accepted. In conclusion, there are significant differences between the average pretest and post-test. The difference can be seen from the post-test average of 67.40 that is higher than the pretest score of 54.34. Related to these results, it can be concluded that the hypothesis is proven true, in which the post-test value is higher than the pretest, both in experimental class and the control class. Therefore, it can be concluded that group investigation model based on hands-on activities is effective to improve the learning outcomes based on students higher-order thinking skills.

The second hypothesis is done to test the truth that the learning outcomes based on students higher-order thinking skills by using group investigation model based on hands on activities is higher than group investigation model. It is proven from the test results in the experimental class that is higher than the result in control class. Therefore, the application of group investigation learning model based on hands on activities is better than the group investigation model in increasing the learning outcomes based on students' higher order thinking skills.

\section{Conclusion}

Based on the research results, it can be concluded that by applying group investigation learning model based on hands on activities is effective to increase the learning outcomes based on students' higher order thinking skills in Economics learning, particularly in the material of market in economy. This can be seen from the value of $\mathrm{P}<0.05$, where the value of $t$ count is -4.300 with the group investigation model and $t$ count of -7.274 by using group investigation model based on hands on activities. Besides, the learning outcomes based on higher order thinking skills by using group investigation learning model based on hands on activities is proven higher than the group investigation model. It can be proven from the test results in the 
experimental class that is higher than the control class. Finally, from the results of the study, it is expected that teachers continually create an innovation to achieve learning objectives. Since learning models selection in delivering material has a big influence on students learning outcomes. The results of the study have also proven that the application of group investigation model based on hands on activities is effective to be done in teaching Economics, particularly in material of market in the economy, so that it is really recommended to use this learning model in the future.

\section{References}

Adi. W. (2003). Genius Learning Strategi. Jakarta: Gramedia Pustaka Utama.

Ates and Eryilmaz. Efectiveness of hands on and minds on activities on students achievement and attitudes towards physics. Asia Pasific Forum on Science Learning and Teaching. Vol. 12, Issue 1, Article 6,P.1.

Brookhart, S. M. (2010). How to assess higherorder thinking skills in your classroom. Alexandria: ASCD.

Chu, S.Y. (2014). Application of the Jigsaw Cooperative Learning Method in Economics Course.International Journal of Managerial Studies and Research (IJMSR). 2. 166-172.

Fathir, S. Penerapan Model Pembelajaran Kontekstual berbasisHands On Activity Pada Materi Statistika Untuk Meningkatkan Motivasi dan Hasil Belajar Siswa. ISSN 2442-9511.Vol. 1 No. 2.

Isjoni. (2009). Pembelajaran Kooperatif Meningkatkan Kecerdasan Komunikasi Antar Siswa. Yogyakarta: Pustaka Pelajar.

Jolliffe, W. (2007). Cooperative Learning in The Classroom. Puting It Into Practice. London: SAGE.

Kartono. (2010). Hands on activity pada pembelajaran geometri sekolah sebagai assesmen kinerja siswa. Jurnal Matematika Kreatif-Inovatif.

Kettunen, J., Kairisto-Mertanen, L., \&Penttilä, T. (2013). Innovation Pedagogy And Desired Learning Outcomes In Higher Education. On the Horizon. 21 (4), 333 - 342. http://www.emeraldinsight.com/doi/10.1108/OTH-08-2011-0024.

King, F. J., Goodson, L., Rohani, F. (2004).Higher Order Thinking Skill.A publication of the Educational Services Program, now known as the Center for Advancement of Learning and Assessment.http://www.cala.fsu.edu/files/higher_order_thinking_skills.pdf

Koc, Doymus, Karacop, \& Simsek. (2010). The Effect of Two Cooperative Learning Strategies on the Teaching and Learning of the Topics of Chemical Kinetics. Journel of Turkish Science Education, 7 (2), 52-65.

Paul, S. (1997). Filsafat Konstruksivisme dalam Pendidikan. Yogyakarta: Kanisius.

Permendikbud. (2013). Peraturan Menteri Pendidikan dan Kebudayaan Republik Indonesia Nomor 81A Tahun 2013 Tentang Implementasi Kurikulum 2013.

Purwanto. (2010). Evaluasi Hasil Belajar. Yogyakarta: Pustaka Pelajar.

Sangadji. (2016). Implementation of Cooperative With Group Investigation Model To Improve Learning Achievement of Vocational School Students In Indonesia.International Journal of Learning \& Development. ISSN 2164-4063. Vol 6, No.1.

Sharan, Y. (1999). Handbook of Cooperative Learning Methods. USA: Praeger Publishers. Slameto. (2010). Belajar dan Faktor-faktor yang Mempengaruhi. Jakarta: RinekeCipta. Wena, M. (2012). Strategi Pembelajaran Inovatif Kontemporer. Jakarta: BumiAksara. 